\title{
人工衛星SAR画像による被害地域検出手法の \\ 2004年新潟県中越地震への適用と高度化 \\ APPLICATION OF SATELLITE SAR BASED DAMAGE DETECTION TECHNIQUE TO THE 2004 NIIGATA-KEN CHUETSU EARTHQUAKE AND ITS UPGRADE
}

\author{
松烊昌志*, 堀江 啓**, 大倉 博*** \\ Masashi MATSUOKA, Kei HORIE and Hiroshi OHKURA
}

\begin{abstract}
Building damage detection technique which we had developed, has been successfully applied to past earthquakes such as the 1995 Kobe, the 2001 India, and the $2003 \mathrm{Bam}$, by using the compound index, $z$-value, which is the value derived from the correlation and difference in intensities between pre- and post-event SAR images. This technique was applied to the affected areas due to the 2004 Niigata-ken Chuetsu earthquake on October 23, 2004, by using one pair of Radarsat images taken before and after the earthquake. However, it was not possible to identify any significant distribution of damaged buildings. In this study, we examined the reason and proposed a new technique by using two pairs (pre-seismic and co-seismic) of SAR images, to identify smaller building damage ratios in less densely built-up areas compared to previous techniques. The main idea is to minimize the effect of signal noise and temporal changes of the earth's surface, on building damage estimation, by calculating the difference values from the two pre-event images and one post-event image. In a macroscopic point of view, the distributions of the both deference values of $z$-value and correlation coefficient in built-up areas were in good agreement with damage by survey reports. In Yamakoshi village, located in highland, we also could identify large-scale landslides with accuracy as good as interpretation from aerial photos.
\end{abstract}

Keywords : Synthetic aperture radar (SAR) image, Damaged area detection, Building damage, Ojiya city, the 2004 Niigata-ken Chuetsu earthquake, Correlation coefficient

合成開ロレーダ (SAR) 画像; 被害検出, 建物被害, 小千谷市, 2004 年新潟県中越地震, 相関係数

\section{1.はじめに}

最近では，各国が打ち上げた人工衛星観測データの相互利用に係 わる国際的な枠組みが整備され，世界各地で多発する災害状況の早 期把握手段としてのリモートセンシング技術の活用が高まってきて いる。その枠組みのひとつに国際災害チャーダがあり、これは， 地球観測衛星による災害管理への貢献の促進を目指した憲章「自然 または人為的災害時における宇宙設備の調和された利用を達成する ための協力に関する憲章」である。この憲章に基づき，世界で災害 の発生が予測される地域あるいは災害が発生した地域を, 地球観測 衛星により優先的に観測し，防災関係機関などへのデータの無償提 供を通して, 緊急事態の支援, 復興および事後処理に資することを 目的とした宇宙機関を中心とする国際協力体制が確立された。1999 年にフランス宇宙研究センター (CNES) と欧州宇宙機関 (ESA) が チャータを発表, 2000 年に調印した後, 複数の宇宙機関が次々と参 加し, 日本も 2005 年 2 月に加入した。これにより，防㷋関係機関等 のユーザからの要求に基づき, 可能な限りの地球観測衛星を用いて 被災地を観測し，その画像データや被災地判読結果は早期かつ無償 で提供されるようになった。
2003 年以降, チャータは年間約 20 回発動されており，世界では月 2 回程度のペースで大規模な自然災害が発生していることがわかる。 主題図は $\mathrm{Web}^{\mathrm{l})}$ でも公開されており，2004 年 12 月のスマトラ沖地震 津波や 2005 年のハリケーン・カトリーナ水害でも発災前後の数多く の観測画像から被災地を推定した主題図が作成された。

衛星画像からは, 例えば, スマトラ沖地震津波では, 画像の地上 解像度が $30 \mathrm{~m}$ 程度であっても, 津波による被害範囲が概ね推定でき, $1 \mathrm{~m}$ の解像度ともなると建物や橋梁などは目視により被害が把握でき

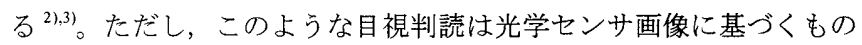
であることから，早期に観測できたとしても雲や雲影の影響で被災 地が見えないことも多い。昼夜を問わず，かつ，雲を透過して地表

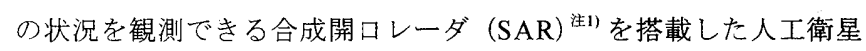
についても被災地を観測するが, 洪水による冠水などの後方散乱特 性に大きな影響を与えるような状況を別とすると, SAR 画像からの 目視による被害判読は非常に困難である。建物や道路等の社会基盤 施設を対象とした場合, 国際災害チャータにて公開された主題図の 内, SAR 画像に基づいたものはほとんどない。SAR 画像を被害検出 に利用する際には，適切な画像処理をすることが必要不可欠である。

* 防災科学技術研究所地震防災フロンティア研究センター チームリーダー・博士 (工学)

(現在 産業技術総合研究所グリッド研究センター)

** 阪神・淡路大震災記念人と防災未来センター 専任研究員 - 博士 (工学) (研究当時 防災科学技術研究所 地震防災フロンティア研究センター)

*** 防災科学技術研究所 総括主任研究員 - 博士 (理学)
Team Leader, Earthquake Disaster Mitigation Research Center, NIED, Dr. Eng.

Researcher, Disaster Reduction and Human Renovation Institute, Dr. Eng.

Senior Researcher, National Res. Inst. for Earth Sci. and Disaster Prevention, Dr. Sci. 
著者らは既に, 1995 年兵庫県南部地震の地震前後に被災地を観測 した人工衛星 SAR 画像（2シーン）に記録される後方散乱 ${ }^{\text {注2 }}$ の強度 の比較から, 建物倒壊等の大規模な被害地域を自動検出する手法を 提案し ${ }^{4)}$ ，他の被害地震に適用することで手法の妥当性を確認してき た ${ }^{5,6)}$ 。また，地震動情報による被害推定と統合処理する高精度化も 試みている7。本報では, SAR 画像による被害検出手法を 2004 年新 潟県中越地震に適用し, 小千谷市での建物被害調查デー夕との比較 から，手法の適用限界を明らかにする。そして，地震前に観測され た SAR 画像を新たに 1 シーン追加することで, 建物密集度の低い地 域にも適用可能で, かつ, 中程度の被害を受けた地域を含む被害検 出が可能な手法を新たに提案する。

\section{2. 既往の被害検出手法の新潟県中越地震への適用}

\section{1 被害検出手法の概要}

1995 年兵庫県南部地震以降，建物被害と SAR 画像の強度情報ある いは位相情報との比較研究が精力的に進められてきた ${ }^{51,88,99}$ 。とくに, 重要なことはSARから得られる強度情報は軌道等の観測条件に大き くは依存しないことから, 強度情報に基づく変化抽出手法は他の地 域への移植性が高い。兵庫県南部地震の前後に観測された欧州宇宙 機関の ERS 衛星のSAR 画像と現地調査データから導かれた被害地域 の検出の考え方と手法 ${ }^{4), 5}$ の概要を以下に示す。

後方散乱強度の大きさはマイクロ波の波長や地表への進入角度（照 射角と入射角)，地表面の凹凸や誘電特性の影響を受けるが，このう ち凹凸だけを考えると図 1 に示すように人工衛星により市街地に対 して照射されたマイクロ波は地面と建物との間での複数反射（カー ジナル効果 ${ }^{\text {i玉 } 31)}$ によって後方散乱強度は大きくなる。一方, 建物 の倒壊地域や空地に照射されたマイクロ波は多方向散乱によって 衛星に戻る成分は小さくなる。その変化は地震前後の後方散乱係数 $\sigma^{0}(\mathrm{~dB})^{\text {生4) }}$ の差分や相関係数の值で表現できる。

まず，2 時期の SAR 画像の正確な位置合わせの後，それぞれの画 像に $21 \times 21$ ピクセルウィンドウのスペックルノイズ注5) 低減フィル 夕 $^{10)}$ を施す。差分は $13 \times 13$ ピクセルウィンドウ内の後方散乱係数 の平均值について差分を求め ((1) 式), 相関倸数についても $13 \times$ 13 ピクセルウィンドウから算出する（(2) 式）。として, 差分と相関 係数を説明変数とした（3）式に示す合成変量（判別得点）に基づき 被害地域を検出する。

$$
d=10 \cdot \log _{10} \bar{I} a_{i}-10 \cdot \log _{10} \bar{I} b_{i}
$$

$$
r=\frac{N \sum_{i=1}^{N} I a_{i} I b_{i}-\sum_{i=1}^{N} I a_{i} \sum_{i=1}^{N} I b_{i}}{\sqrt{\left(N \sum_{i=1}^{N} I a_{i}^{2}-\left(\sum_{i=1}^{N} I a_{i}\right)^{2}\right) \cdot\left(N \sum_{i=1}^{N} I b_{i}^{2}-\left(\sum_{i=1}^{N} I b_{i}\right)^{2}\right)}}
$$

$z=-2.140 d-12.465 r+4.183$

ここで, $d$ は後方散乱係数の差分值, $r$ 柱相関係数, $z$ は判別得点を 表し，Nは計算するウィンドウ内のピクセル数を表す。 $13 \times 13$ ピク セルのウィンドウを用いるため, $N$ は 169 となる。地震前後の 2 時 期であれば, $I a_{i}, I b_{i}$ は地震後と地震前のそれぞれの画像の $i$ 番目にお

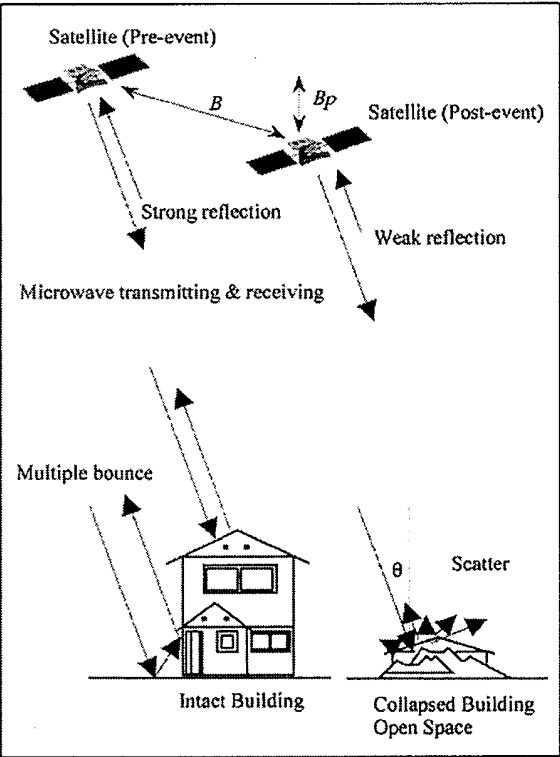

図 1 人工衛星 SARによる観測の模式図.

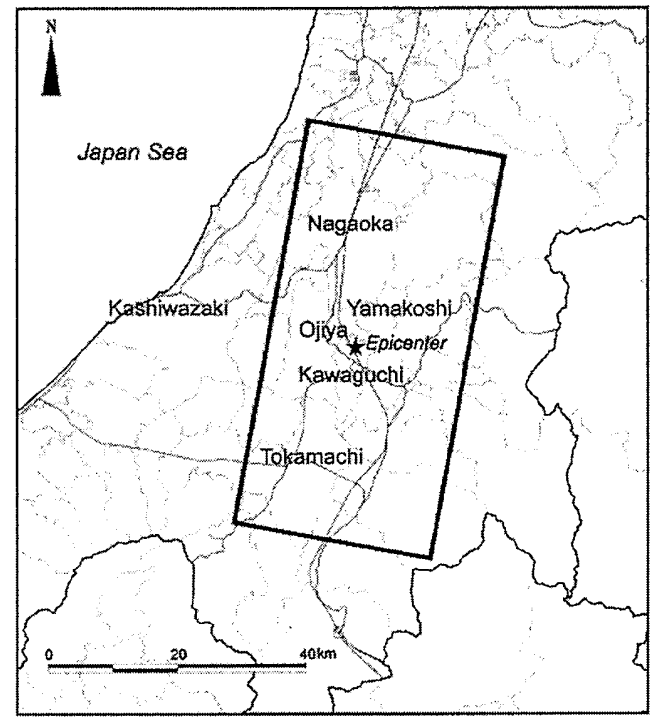

図 22004 年新潟中越地震の解析対象範囲（矩形部分）.

けるピクセル值, $I a_{i}, I b_{i}$ は $i$ 番目におけるピクセルの周囲 $13 \times 13$ ピクセルの平均值である。ここで用いるフィルタやウィンドウサイ ズは ERS 画像（ピクセルサイズ $30 \mathrm{~m}$ ） と兵庫県南部地震での街区単 位で整理された建物被害調査データ ${ }^{11)}$ との比較に基づき，スペック ルノイズを低減しつつ被害の判読精度が高くなるように経験的に決 定したものである。判別得点 $z$ の值が大きいほど地表変化が大きく， 被害が甚大である可能性が高い。なお，対象地域をカージナル効果 が期待される市街地に限定するため，後方散乱係数が - 5 - $6 \mathrm{~dB}$ 以下 の地域はマスクする。

\section{2 新潟県中越地震への適用}

2004 年 10 月 23 日にマグニチュード $(\mathrm{Mw}) 6.5$ の地震が新潟県中越 地方で発生し, 死者 40 名, 負傷者約 3,000 名, 住宅の全半壊 1 万棟 以上という大きな被害をもたらした。また，斜面崩壊，液状化等に よって道路施設, 農業施設, ライフラインにも大きな被害をもたらし， 


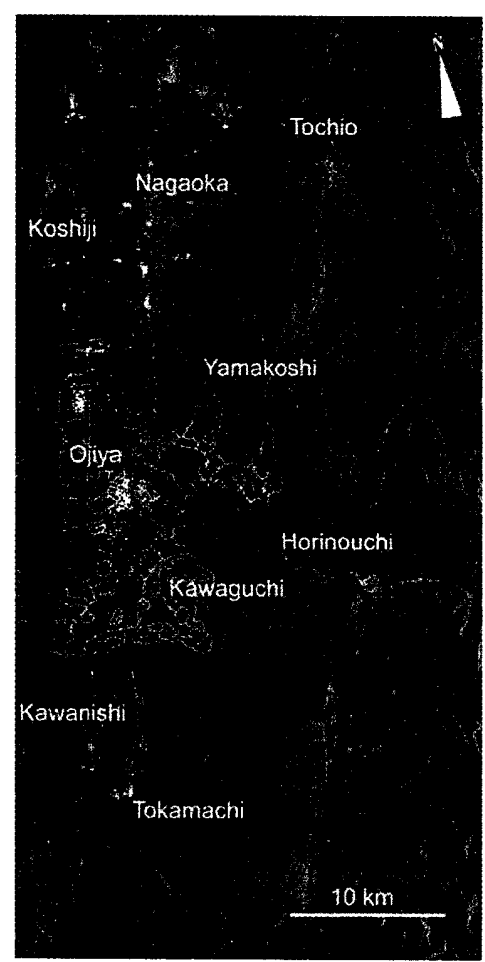

図 3 新潟県中越地震後の 2004 年 10 月 25 日に 観測された Radarsat/ Fine 強度画像. 白線 は小千谷市の行政界。
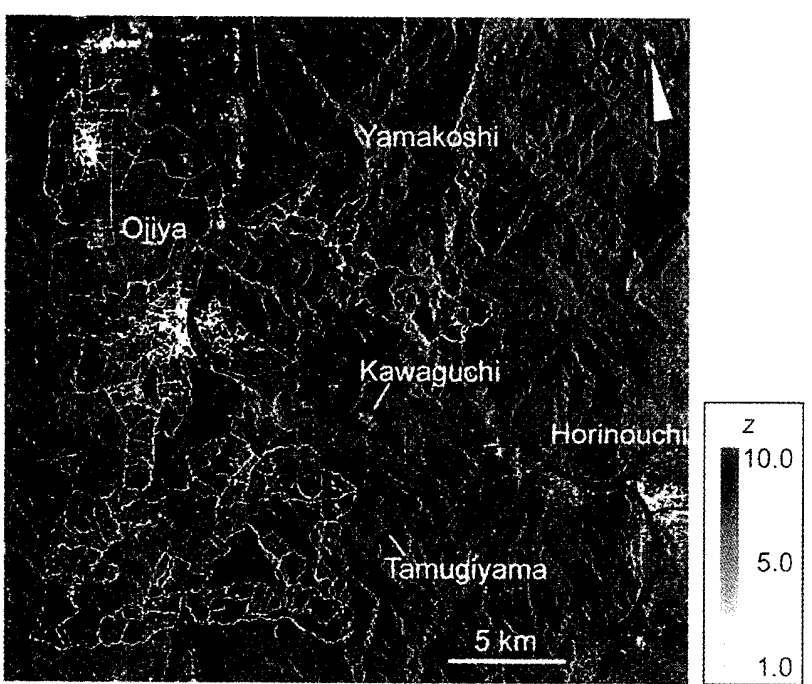

図 4 小千谷市周辺での判別得点 $z$ の分布（背景は地震前の 2004 年 10 月 1 日観測の強度画像).

とくに, 全国有数の地すべり多発地域である旧山古志村は震源直近 ということもあり，多数の斜面崩壊や地すべりが発生した。夕刻の 地震ということもあり，地震直後から收集できた被害情報は限られ ていたが，翌日からのへリテレ映像や航空写真 ${ }^{121}$ ，そして，高分解 能 IKONOS 衛星の画像 ${ }^{13)}$ から被害の全体像を理解した人も多い。

SAR を搭載した衛星は, 地震の 2 日後にカナダ宇宙庁の Radarsat 衛星 ${ }^{14)}$ が Fineモード（Cバンド, HH 偏波, 地上解像度は約 $9 \mathrm{~m}$ ) にて被災地を観測している。本研究では, SLC (Single Look Complex)

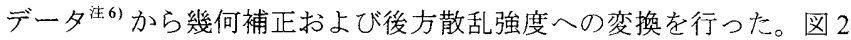
には画像の範囲を, 図 3 には地震後の強度画像を示す。地震前の画 像には2004年 10 月 1 日に観測されたものがある。そこで，前述し

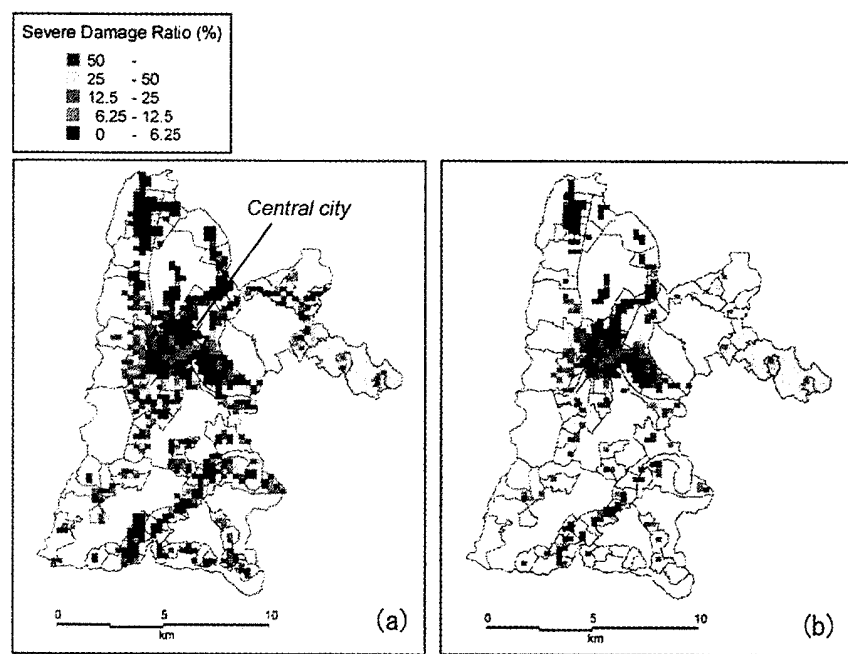

図 5 小千谷市の建物全壊率 $(250 \mathrm{~m}$ メッシュ単位) の分布。(a) メッ シュ内に調查建物がある地域，(b) メッシュ内に調查建物が 10 棟以上ある地域. なお，北東部の網がけの部分は積雪によ る被害の影響が含まれる地域。

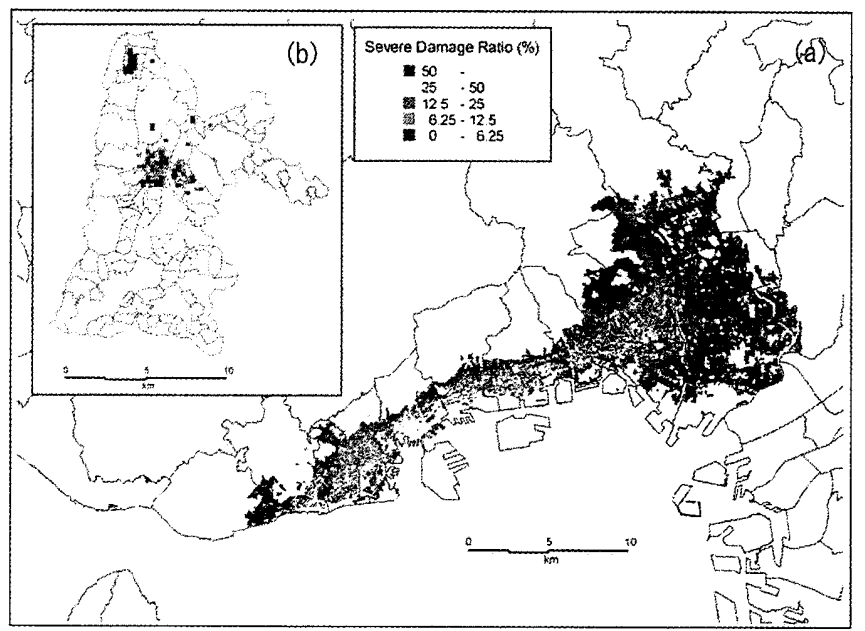

図 6 被害調査データに基づく建物全壊率の分布.（a）兵庫県南部地 震における阪神地域，(b) 新潟県中越地震における小千谷市 (メッシュ内の建物が 50 棟以上ある地域).

た手法を地震前後の Radarsat画像に適用し，建物被害地域の検出に ついて検討した。図 4 にその小千谷市周辺の結果を示す，兵庫県南 部地震 $^{4)}$ や1999 年トルコ・コジャエリ地震 ${ }^{5)}$ などとは異なり, 市街 地において被害地域がほとんど検出されない。

以降では，小千名市において地震後に実施された建物被害調查を 整理したデータに基づき，この検出結果の評価を行うと共に，小千 谷市の建物被害を検出できる方法の開発を進める。

\section{3. 建物被害と後方散乱特性の関係}

\section{1 小千谷市の建物群と被害についての考察}

震源に比較的近い小千谷市（図 3，図 4 中の白線が行政界を表す） では, 罹災証明書発行のために, 国の被害認定基準に従って判定訓 練を受けた行政職員が主体となって建物の悉皆調査を実施し, 結果 がGIS データベースとして収録されている ${ }^{15}$ 。それによると, 全 半壊あわせて約 3,300 棟の住家で被害が発生している。非住家を含 
めた建物の全壊率は町字単位での集計によると, 中心市街地で概ね 0 20\% 程度であるのに対して, 市の北東部や西から西南部にかけて の地域では 10 50\% 程度と中心市街地よりも大きい傾向が確認され

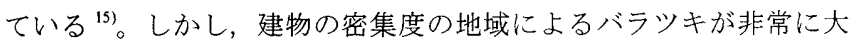
きい。より明確に被害の大きい地域を同定するために，調査対象建 物が存在する地域についてのみ選定し，1/4 基準地域メッシュ（約 $250 \mathrm{~m}$ 四方）単位で全壊率を算出した結果を図 5(a)に示す ${ }^{15}$ 。全懐 率は中心市街地よりも北東地区や南西地区において高いことが読み 取れる。しかし，メッシュ内の調查建物が 1 棟しかないなど, 母数 が極端に少ない地域も多いことから，依然として信頼性の高い被害 分布とは言い難い。そこで, 調查建物が 10 棟以上あるメッシュに限 定した場合の全壊率分布を図 5(b) に示す。中心市街地を除く広い範 囲で対象メッシュ数が減少し, 全壊率が高い地域がやや少なくなる。

次に，2 章にて紹介した手法に基づいて推定した被害分布（図 4) が実際の被害状況を説明できなかった要因について, 検出手法構筑 の基礎となった兵庫県南部地震での被害や建物密集度と対比させて 検討する。前述したように本検出手法は, SAR 画像に特徽的な建物 群のカージナル効果とその変化に基づいていることから, 建物密集 度や都市域の広がりが重要なファクターとなる。

図 6(a) には兵庫県南部地震における被害調查データ ${ }^{11)}$ に基づき, 街区単位で整理した阪神地域の低層建物全壊率を示す。東西方向に 全壊率の高い地域（いわゆる震災の帯）が分布する。なお，地震動 強さを考慮したフラジリティ関数によると, 兵庫県南部地震におけ る被害調査データから求まる全壊率と小千谷市が参考にした国の被 害認定基準による全壊率とは大差がない ${ }^{16)}$ 。こ GIS データからは, 街区内に扔ける平均的な建物密度は約 $580 \mathrm{~m}^{2}$ に対して 1 棟となり,

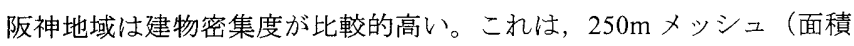
は $62,500 \mathrm{~m}^{2}$ ) であれば，約 100 棟存在するということになる。 $250 \mathrm{~m}$ メッシュで分割した際には街区の外の道路部分も含むこと, 地方の 市では建築面積が大都市よりも大きいことなどを考慮して，小千谷 市については，250m メッシュ内に50 棟以上の建物がある地域を建 物密度が高い地域として選定すると, 図 6(b) のようになる。阪神地 域での被害分布（図 6(a)）と比較しても明らかなように，小千谷市 において建物密度が高い地域は非常に狭い地域に限定され，しかも， 建物全壊率が $12.5 \%$ 以下が大半を占める。

したがって，この結果を既往の報告 ${ }^{4)-6)}$ と総合すると，本被害検 出手法の適用範囲は, 建物が密集している都市域において建物全壊 率が $25 \%$ 程度以上であり, 被害域がある程度の広がりを持っている 場合に，無被害あるいは小被害地域と区別して検出する能力がある と考えられる。

\section{2 後方散乱特性の時系列変化と建物全壊率との関係}

前節で示したように，カージナル効果が地震後には減少する現象 のみを主として期待する本被害検出手法は, 地震前後の 2 シーンを 利用するといら簡便性があるものの，適用限界があることも明らか になった。そこで，用いるシーン数が増えることを許容しても，小 規模な市町村が分布する地域に適用可能な被害検出手法を構筑する ことを試みる。

リモートセンシング画像を利用して地震による被災地の推定を試 みる際には, 地震前後の 2 シーンの単純比較よりも, 複数シーンを 用いた時系列分析の方が良好な結果を示すことが, DMSP 衛星の夜

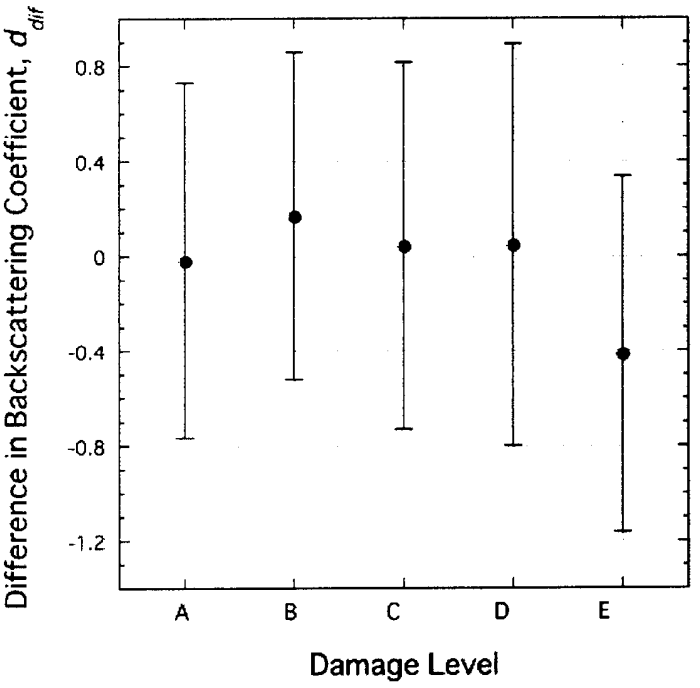

(a) 後方散乱係数差分の差分 $d_{d i f}$

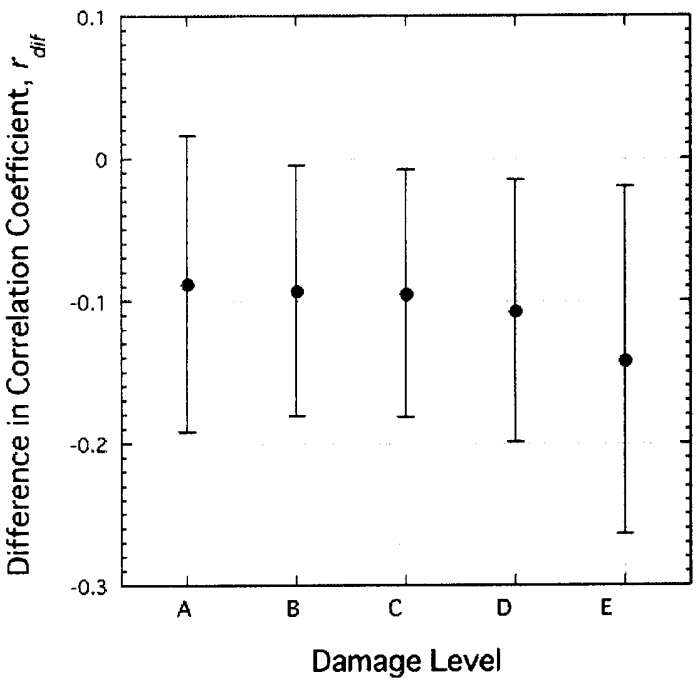

(b) 相関係数の差分 $r_{\text {dif }}$

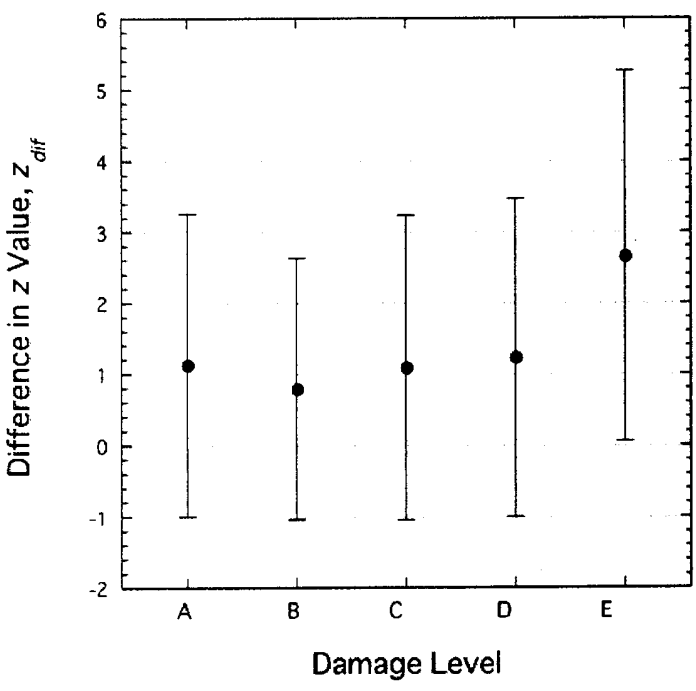

(c) 判別得点の差分 $z_{\text {dif }}$

図 7 後方散乱特性の変化と小千谷市の建物被害レベル（A: 建物 全壊率 $0 \sim 6.25 \%, \mathrm{~B}: 6.25 \sim 12.5 \%, \mathrm{C}: 12.5 \sim 25 \%$, D: $25 \sim 50 \%$, E: $50 \sim 100 \%)$ との関係. 
間画像の解析から示唆され ${ }^{177}$, また, 夜間の光の動態だけでなく, 昼間に光学センサ画像が記録した分光反射情報の時系列解析からも， 甚大被害地域が検出可能との事例がある ${ }^{18)}$ 。SAR 画像については, 地震前 2 シーンと地震後 1 シーンを利用して, これらの位相情報の 組み合わせによる干渉処理から建物被害の確率を推定する試みもあ

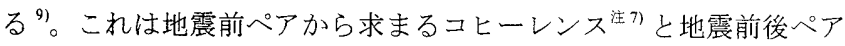
のコヒーレンスを比較することで，時間経過に伴うコヒーレンスの 減少を評価しつつ建物被害を推定するものであるが ${ }^{9}$ ，衛星間距離に 起因するコヒーレンスの $\mathrm{S} / \mathrm{N}$ 比の低下は避けられず，3 時期における 衛星軌道が近いことが適用の条件となる。

そこで, 本研究においても地震による大きな変化がない時期にお けるSARの後方散乱特性の定常的な変化状態をあらかじめ把握して, 地震後における後方散乱特性の変化を相対評価する考え方を応用し， その指標の変化と建物被害率との関係を検討する。しかし，文献 9) とは異なり，指標の算出に SAR 画像の強度情報を利用することで, 衛星軌道等の観測条件の影響を受汁ない汎用性の高い手法の構築を 試みる。

地震前の Radarsat 画像（2004 年 10 月 1 日）よりも前に新潟県中越 地方を観測した画像に 2004 年 9 月 7 日のものがある。本研究では, この画像を地震前画像として新たに追加した。そして，地震前画像 のペアから, 後方散乱係数の差分 $\left(d_{b b}\right)$, 相関係数 $\left(r_{b b}\right)$, 判別得点 $\left(z_{b b}\right)$ を(1) （3）式を用いて算出した。そして，地震前後画像のベア から既に算出済みの $d, r, z$ から, 後方散乱係数の差分のさらに差分 $\left(d_{d i f}\right.$ $\left.=d-d_{b b}\right)$, 相関係数の差分 $\left(r_{d i f}=r-r_{b b}\right)$, 判別得点の差分 $\left(z_{d i f}=z\right.$ $\left.-z_{b b}\right)$ を求め, これらの指標の桨化と建物全壊率との関係老検討する。 検討にあたっては，建物が存在する地域をあらかじめ抽出してお く必要がある。2 章に示した検出手法では, 建物群のカージナル効果 を想定し, 地震前画像において後方散乱強度が大きい地域を選定し ているが，本検討では，地震前画像を新たに追加したことによる利 点を生かし，地震前画像ペアにおいて変化が小さい(後方散乱特性 が安定している）地域を選定することにした。今回のデータセット は，地震前同士の衛星軌道間距離 $B p$ が約 $340 \mathrm{~m}$ と比較的短いことか ら，マイクロ波の位相情報から求まるコヒーレンスを利用した。コ ヒーレンスの方が地表の凹凸に敏感であり，建物群の判別に適して いるからである ${ }^{19}$ 。コヒーレンスは $5 \times 5$ ピクセルのウィンドウ空 から算出し，その空間分布から闌値を 0.3 と判断して，その値以上の 地域は建物が存在する可能性が高いと考え, 検討対象地域として抽 出した。

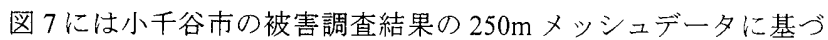
く被害レベルと各種指標の差分, $d_{d i f}, r_{d i f}, z_{d i f}$ の関係を示す。なお， メッシュ内の調査建物棟数が 10 棟未満の地域と冬期積雪による影響 が含まれる地域は除いた。ここで，被害レベルとは建物全壊率に応 じて 5 区分したもので，既往研究 ${ }^{5)}$ を踏襲して，全壊率が $0 \sim 6.25 \%$ を被害レベル A， 6.25 12.5\%を B，12.5 25\%を，C，25 50\%をD， 50 100\%を Eとした。また, 被害レベルごとに該当するピクセル数 にはバラツキがあるので, それぞれ 1,000 ピクセルを無作為に抽出し, 平均值と標準偏差を求めている。図 7 より, 大局的にみ机被害レ ベルが大きくなるにつれて， $d_{d i f}$ と $r_{d i f}$ の值法隇少し,それに伴い， $z_{d i f}$ の値は大きくなる。被害地域では後方散乱強度が減少し，相関も低 下するという2 章での仮定と矛盾しない。分散分析 ${ }^{201}$ によれば，被
害レベル A と $\mathrm{E}$ との間では, 有意水準 $1 \%$ で $F$ 比は有意となる。また, 相関比は大きい順に, $z_{d i f}>d_{d i f}>r_{d i f}$ となり, 判別得点の差分 $z_{d i f}$ が被 害レベルを区分するのに最も適していることになる。しかし， $r_{\text {dif }}$ の

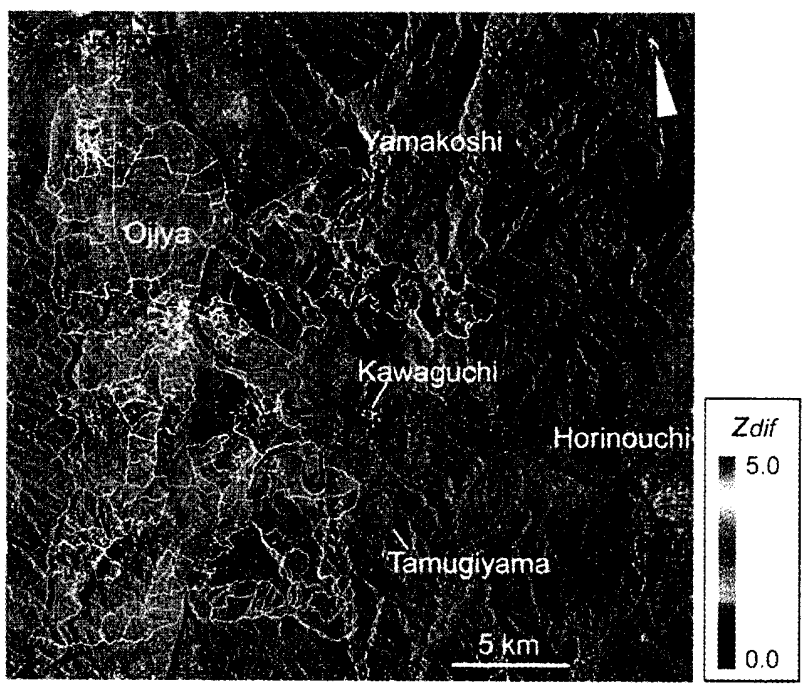

図 8 小千谷市周辺での判別得点の差分 $z_{\text {dif }}$ の分布（背景は地震前の 2004 年 10 月 1 日観測の強度画像)。対象地域は地震前画像へ アのコヒーレンスが 0.3 以.上の地域.

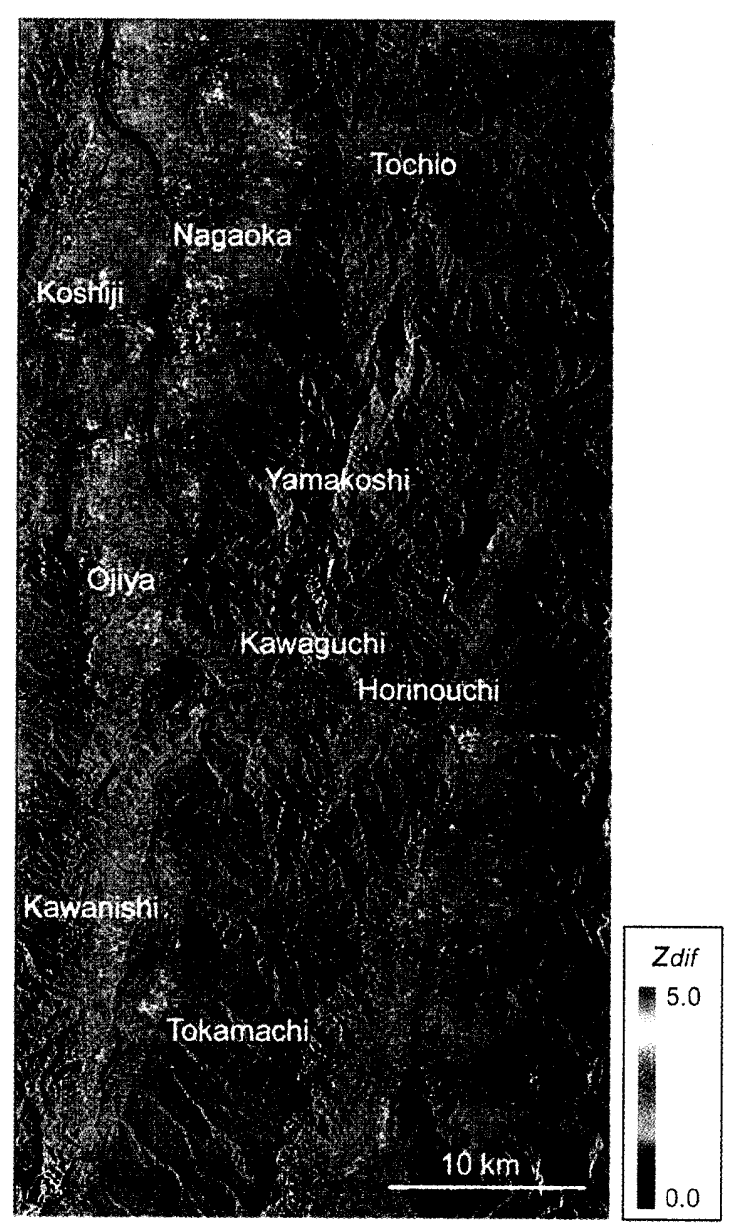

図 9 Radarsat/Fine 画像全域から算出した判別得点の差分 $z_{d i f}$ の分布 (背景は地震前の 2004 年 10 月 1 日観測の強度画像). 対象地 域は地震前画像ペアのコヒーレンスが 0.3 以上の地域. 
大小は被害レベルとの傾向に合っているものの， $z_{d i f}$ と $d_{d i f}$ は被害レ ベル B の值が逆転しており，被害レベルが小さい範囲での傾向には ややバラツキがある。

\section{4. 時系列変化を利用した被害地域の検出手法}

\section{1 判別得点の差分による被害地域の検出}

3 章での検討を踏まえ, 地震前 2 シーン, 地震後 1 シーンの Radarsat 画像から, 判别得点の差分 $z_{d i f}$ の分布を求め, 地震前の強度 画像に重ねた。小千谷市と川口町, 旧堀之内町周辺の拡大図を図 8 に示す。コヒーレンスが 0.3 以上の範囲を対象地域としている。着色 されていない地域や寒色系の地域は建物被害の可能性が低いことを 示している。小千谷市では中心市街地よりも西部から南西部にかけ て被害が大きい傾向（図 5）を $z_{d i f}$ の分布も表しており，大きな被害 を受けた川口町の中心市街地や田麦山地区についても $z_{d i f}$ の值は大き い。全壊率が $50 \%$ 以上の地域仙判別得点の差分 $z_{d i j}$ が 2.5 程度以上の 地域に概ね対応する。

実用的な被害検出手法とは被害地域を検出するだけでは不十分で あり，無被害地域については被害として検出されないことが肝要で ある。そこで, 画像全域について判別得点の差分 $z_{d i j}$ の分布を求めた（図 9 参照)。これより, 長岡市南部から小千谷市, 川口町, 旧堀之内町, 旧川西町にかけて $z_{d i f}$ の值が大きい（被害の可能性が高い）地域が分 布し，一方，長岡市中心部や旧越路町，十日町市では逆に $z_{d i f}$ の值が 小さい。この特徵は広域的に建物被害を調査した報告 ${ }^{21)}$ と良い詨応 を示す。以上のように，判別得点の差分 $z_{\text {dif }}$ を用いることで，建物密 集度が低い地域についても被害地域が㭘出でき，かつ，被害域の全 体像が把握できることがわかる。

\section{2 相関係数のみを利用した被害地域の検出}

上述のように検討対象地域（後方散乱特性が安定した地域）の選 定には，位相情報から算出したコヒーレンスを用いたが，この值は 衛星の軌道間距離 $B p$ や観測間隔などの観測条件に強く依存し ${ }^{8)}$, 利 用できる機会が少ない。一方，強度画像の相関は観測条件の制約を それほど受けない ${ }^{8)}$ 。したがって，災害時や緊急時の実用的な被害把 握を考えた場合，相関係数を用いる方が現実的である。そこで，地 震前画像のペアから算出した相関係数 $r_{b b}$ から対象地域を選定するこ とを考えた。また，相関係数はピクセル值の較正が十分でない場合 でも，安定した值が得られることから，相関係数のみに着目した被 害地域検出が可能であれば，より壳長的な被害検出システムの構築 が可能となる。

相関係数差分 $r_{d i f}$ の分布を強度画像に重ねた結果を図 10 に示す。 $r_{b b}$ の值が 0.8 以上を対象地域としている。被害を受けた可能性高い 地域（ $r_{d i f}$ の值が小さい地域）を暖色系にしている。大きな被害を受 けた小千谷市から川口町や田麦山にかけて $r_{d i f}$ の值が小さい地域が分 布し，実際の被害 ${ }^{21)}$ との対応も良い。図 11 には画像全域における結 果を示寸が, $r_{d i f}$ の分布は $z_{d i f}$ の分布（図9）と定性的には良く類似し， 小千谷市や川口町と比べると長岡市中心部や旧越路町では $r_{d i f}$ の值が 大きい地域が分布する。建物全壊率が $50 \%$ 以上の地域は $r_{d i f}$ が -0.15 程度以下の地域と概ね対応する。

さらに，図11 からは，旧山古志村を中心とした山間地において， $r_{d i f}$ の值が小さい地域（緑～赤色）が局所的に存在することがわかる。 その分布は航空写真等から判読した斜面災害発生箇所 ${ }^{22)}$ やIKONOS
衛星の植生指標から推定した被害地域 ${ }^{23)}$ と良い対応を示すことから， 地すべりや斜面崩壊によって地表の凹凸が変化したことに伴い，相 関係数が低下したと考えられる。しかし，山間地においては，SAR

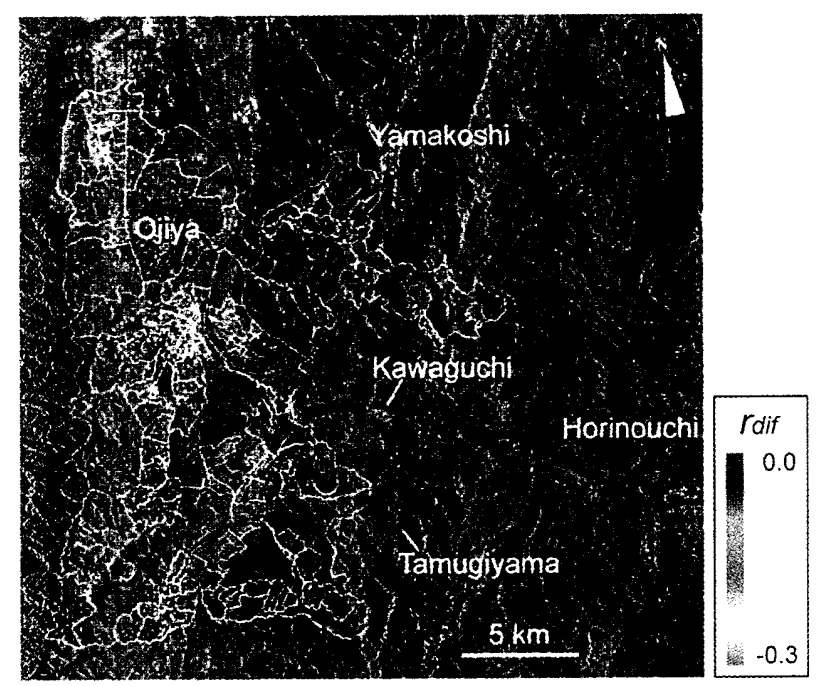

図 10 小千谷市周辺での相関係数の差分 $r_{d i f}$ の分布（背景は地震前 の 2004 年 10 月 1 日観測の強度画像)。対象地域は地震前画 像ペアの相関係数が 0.8 以上の地域.

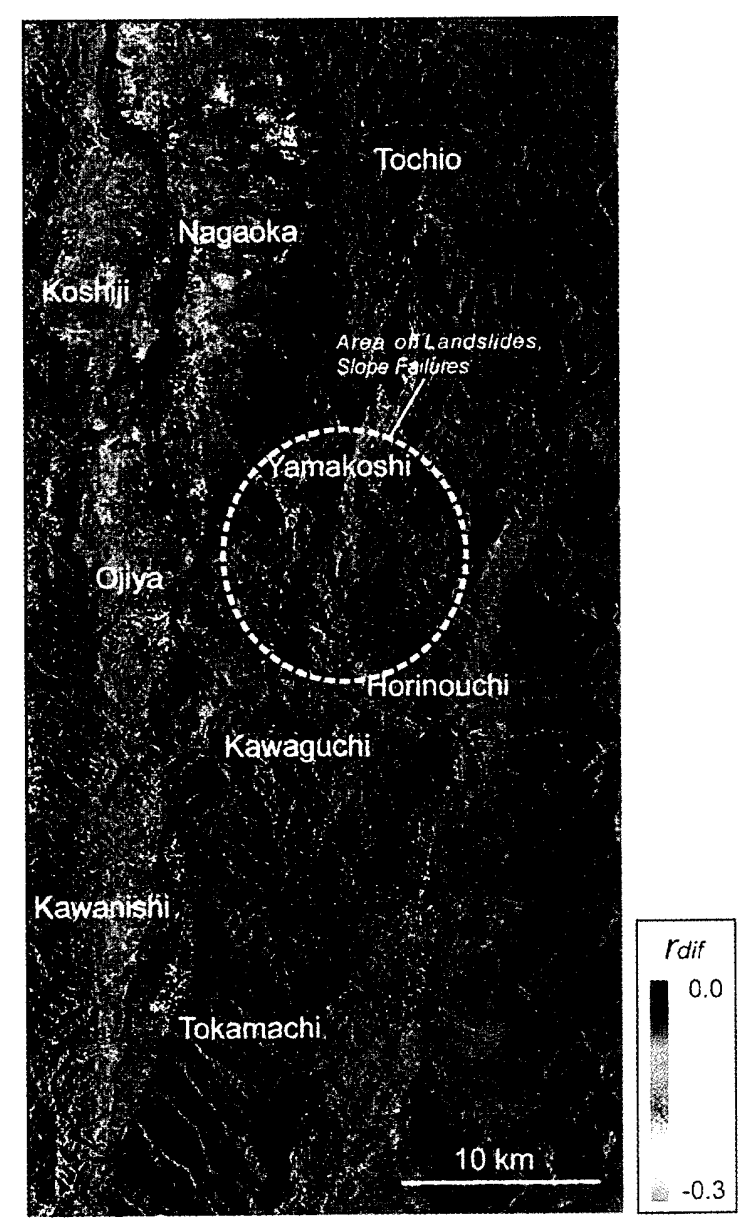

図 11 Radarsat/Fine 画像全域から算出した相関係数の差分 $r_{d i f}$ の分布 (背景は地震前の 2004 年 10 月 1 日観測の強度画像). 対象地 域は地震前画像ペアの相関係数が 0.8 以上の地域. 
画像特有の幾何学的な歪み(レイオーバー裙), フォアショートニン グ主9)，陰影効果 $\left.{ }^{\text {住 }}{ }^{(0)}\right)$ があるために，位置によっては検出が困難なも のがある。今後, 標高データなどから地形の影響を考慮し, 検出限 界を明らかにしていく必要がある。

以上のように，相関係数のみに着目した場合，市街地における建 物被害だけではなく，山間部における地盤災害も検出できる能力が あることが示唆される。しかし，河川の中州や調整池などの水域境 界部の変化が大きい地域も検出されてしまう久点もある。画像処理 による検出結果のみから被害地域を判断するのではなく，原画像と の対比をすることが誤判断を防ぐには重要である。

\section{5. まとめ}

地震前後の人工衛星 SAR 画像 (2 シーン) の後方散乱俰数の変化 と相関係数から算出される合成変量（判別得点）に基づく建物被害 地域の検出手法を，2004 年新潟県中越地震の Radarsat 画像に適用し, 小千谷市の建物被害調查データとの比較から, 建物密集度が低い地 域における手法の適用限界を明らかにした。さらに, 地震前の画像 を新たに 1 シーン追加した 3 シーンを用いて, 地震前画像ペアから 得られる定常状態での相関係数や判別得点に対する地震後のそれら の変化を差分值として算出し, 建物全壊率との関係を検討した。そ の結果, これらの差分值と被害レベルとは良い関係にあり，建物密 集度が低い地域であっても被害が検出できることを示した。また， 相関係数のみに基づく手法では, 斜面災害地域の検出も示唆され, 広範な形態の被害地域を検出できる可能性を示した。相関係数を利 用する場合は, SAR 画像の後方散乱強度の厳密な較正が必要ないこ とから,より年長的かつ実用的な被害地域の早期検出システムへと 容易に発展させることが可能と考えられる。

しかし，提案手法から得られる推定被害域には，画像取得間隔が 長い場合には地震被害以外の地表変化も含まれる。さらに, SAR 画 像に含まれるスペックルノイズを考えると, 画像解像度と比べてよ り大規模な被害域が検出対象となる。今後, 災害把握を目的として 複数の高解像度衛星を打ち上げる計画がある ${ }^{24)}$ ここれにより, 観測 頻度が格段に増し, さらに, 解像度も現状より向上することから, 上記の問題点は克服され，被害検出精度が高まることが期待される。

\section{謝辞}

この研究の一部は科学研究費補助金（課題番号:17510155）によっ た。Radarsat はカナダ宇宙庁所有のものである。図 6 の一部は建築研 究所が国土地理院長の承認を得て, 同院発行の数值地図 10000 ( 総合) を複製した CD-ROM データに基づいて作成したものである（承認番 号平 8 総複,第 26 号)。記して謝意を表する次第である。

注

注 1) 高分解能のマイクロ波映像レーダ。航空機や衛星などのプラットフォー ムに搭載され，小さな寸法のアンテナを用いたままでプラットフォーム の移動に伴い仮想的に大きなアンテナを合成し，それによって高分解能 を実現する。

注 2) プラットフォームの側方からマイクロ波を照射し, 地表で散乱された波 のうち，そのプラットフォームに戻ってきたマイクロ波。記録したマイ クロ波からは振幅（強度）と位相が算出できる。

注 3) 対象物をレーダで走查する場合，同じ対象物であっても視る角度によっ て反射強度が異なる。都市域では建物壁と道路面がリフレクタの働きを することが多く，反射強度は大きくなる場合が多い。
注 4) 単位面積あたりのレーダ散乱断面積（散乱物体のレーダ再放射の大きさ に比例）を散乱係数と㭔ぶ。そのうち，後方への散乱のみを考えたもの。

注 5) レーダ画像など, コヒーレント光学系で撮影された画像に現れるノイズ。 レーダ画像を拡大して 1 分解能セル程度の尺度で見ると，たとえ地表面 が均一な散乱体であっても，セルごとに濃度のゆらぎが認められる。散 乱の際の干渉効果によるもので，コヒーレントな波を利用するレーダで は避けられないもの。完全にノイズ除去することは出来ないが，ノイズ を低減させるための画像処理フィルタはスペックルノイズ低減フィルタ と呼ばれている。

注 6) 合成開ロレーダの画像フォーマットのひとつで，画像として認識できる 振幅 (強度)の情報に加え，位相の情報もあわせもつデータ(複素データ)。

注 7) 2 つ波動の可干渉性を表す指標。レーダはコヒーレントな電磁波なた め可干渉性が優れている。

注 8) マイクロ波映像レーダにおいて，地表対象物がマイクロ波の照射方向上 で軌道に向かって倒れ込むように表現されるレーダ画像特有の幾何学的 歪办。

注 9) マイクロ波映像レーダにおいて，レイオーバーの効果に伴い，相対的に 軌道に向かって傾斜する斜面は実際よりも短くかつ急傾斜に，逆方向に 傾斜する斜面はより長くかつ緩傾斜に画像上に表現される現象のこと。

注 10) 影の分布により地形特徵などが強調される効果。マイクロ波映像レーダ では，照射源側の斜面が光翬部，その反対側が陰影部となる。

\section{参考文献}

1) 国際災害チャータ : International Charter "Space and Major Disaster", ( オンラ イン), 入手先〈http://www.disasterscharter.org/〉, (参照 2006-10-1).

2) Yamazaki, F., Matsuoka, M., Warnitchai, P. Polngam, S., and Ghosh, S.: Tsunami Reconnaissance Survey in Thailand Using Satellite Images and GPS, Asian Journal of Geoinformatics, Asian Association on Remote Sensing, Vol.5, No.2, pp.53-61, 2005.5

3) Miura, H., Wijeyewickrema, A., and Inoue, S.: Evaluation of Tsunami Damage in the Eastern Part of Sri Lanka due to the 2004 Sumatra Earthquake Using Remote Sensing Technique, Proc. 8th U.S. National Conference on Earthquake Engineering, Paper No.856, 2006.4

4) Matsuoka, M. and Yamazaki, F.: Use of Satellite SAR Intensity Imagery for Detecting Building Areas Damaged due to Earthquakes, Earthquake Spectra, Vol.20, No.3, pp.975-994, 2004.8

5) 松岡昌志, 山崎文雄 : 人工衛星 SAR 強度画像を用いた被害地域検出手法 の最近の地震への適用とその妥当性の検討, 日本建築学会構造系論文集, No.558, pp.139-147, 2002.8.

6) Matsuoka, M., and Yamazaki, F.: Building Damage Mapping of Iran Earthquake Using Envisat/ASAR Intensity Imagery, Earthquake Spectra, Vol.21, No.S1, pp.S285-S294, 2005,12.

7) 能島暢呂, 松岡昌志, 杉戸真太, 江崎賢一: 地震動情報と人工衛星 SAR 画 像情報の統合処理による建物全罗率の定量的推定手法の開発, 土木学会論 文集 A, Vol.62, No.4, pp.808-821, 2006.10.

8) Yonezawa, C. and Takeuchi, S.: Decorrelation of SAR Data by Urban Damages Caused by the 1995 Hyogoken-Nanbu Earthquake, International Journal of Remote Sensing, Vol.22, No.8, pp.1585-1600, 2001.5.

9) 伊藤陽介, 細川值史 : 干渉 SAR データを用いた地震被害度推定モデル, 電 気学会論文誌 C, Vol.122-C, No.4, pp.617-623, 2002.4.

10) Lee, J. S.: Digital Image Enhancement and Noise Filtering by Use of Local Statistics, IEEE Trans. Pattern Analysis and Machine Intelligence, Vol.2, No.2, pp.165-168, 1980.3.

11) 建設省建築研究所: 平成 7 年兵庫県南部地震被害調查最終報告書, 1996 .

12) 大木章一, 浦部ぼくろう: 新潟県中越地震における国土地理院の写真測量 分野の対応，写真測量とリモートセンシング，Vol.44, No.1, pp.44-45, 2005.3.

13) 向山栄: IKONOS 衛星画像を利用した地震発生直後における総覧的災害情 報の取得，写真測量とリモートセンシング，Vol.44, No.1, pp.55-57, 2005.3.

14) カナダ宇宙庁 : Canadian Space Agency, (オンライン), 入手先〈http://www. espace.gc.ca/asc/eng/satellites/radarsat1/>, (参照 2006-10-1).

15) 堀江啓, 林春男, 牧紀男, 吉富望, 重川希志依, 田中聡, 沖村孝, 鳥居宣之: 新潟県中越地震による小千谷市の建物被害分布に関する一考察，第 24 回日 本自然災害学会学術講演会講演概要集, pp.7-8, 2005.11.

16) 堀江啓, 林春男, 田中聡, 長谷川浩一, 牧紀男, 沖村孝 : 地震による木 造建物の損傷度を反映する被害関数の構筑，地域安全学会論文集，No.5, 
pp.123-132, 2003.11.

17) Kohiyama, M., Hayashi, H., Maki, N., Higashida, M., Kroehl, H. W., Elvidge, C. D., and Hobson, V. R.: Early Damaged Area Estimation System Using DMSPOLS Night-Time Imagery, International Journal of Remote Sensing, Vol.25, No.11, pp.2015-2036, 2004.6.

18) Kohiyama, M. and Yamazaki, F.: Image Fluctuation Model for Damage Detection Using Middle-resolution Satellite Imagery, International Journal of Remote Sensing, Vol.26, No.24, pp.5603-5627, 2005.12.

19) Zebker, H. A. and Villasenor, J.: Decorrelation in Interferometric Radar Echoes, IEEE Transactions on Geoscience and Remote Sensing, Vol.30, No.5, pp.950-959, 1992.9 .

20) 石川貞夫 : 分散分析のはなし, 東京図書, 1992.2 .
21）吉見雅行，小松原玩，宮地 良典，木村克己，吉田邦一，関口春子，佐伯昌之， 尾崎正紀，中澤努，中島礼，国松直，竿本英貴：2004 年 10 月 23 日新潟 県中越地震被害調查-構造物被害と地形との関係. 地質ニュース, No.607, pp.18-28, 2005.3.

22) 国土地理院：新潟県中越地震災害状況図，2004.10,

23) 三浦弘之, 翠川三郎 : 高分解能衛星画像にみられる2004 年新舄県中越 地震での斜面災害発生籄所の特徴, 第 12 回日本地震工学シンポジウム, pp.1514-1517, 2006.11

24) 産経新聞: 地球観測衛星新たに 4 基 1 時間で被災地画像「偵察」並み分解 能 , 2006 年 10 月 29 日朝刊 3 面, 2006.10 .

(2006年 9 月 6 日原稿受理，2007年 3 月 9 日採用決定） 